\title{
Gypsum and Phosphorus Influence the Initial Growth of Schinus Terebinthifolius Raddi
}

\author{
Natália Hilgert de Souza Carnevali ${ }^{1}$ (D) 0000-0003-0242-7043 \\ Marlene Estevão Marchetti ${ }^{2}$ (1) 0000-0001-6295-0720 \\ Thiago de Oliveira Carnevali ${ }^{3}$ (I) 0000-0002-2577-6601 \\ Maria do Carmo Vieira ${ }^{2}$ (D) 0000-0001-7047-3848 \\ William de Andrade Silva ${ }^{4}$ (1) 0000-0003-2077-9448
}

\begin{abstract}
Because of the lack of agronomic information regarding cultivation of the pink pepper (Schinus terebinthifolius), this study aimed to verify the effect of gypsum and phosphorus on the initial growth and how they affect soil fertility. The treatments consisted of four levels of agricultural gypsum $\left(0 ; 750 ; 1,500\right.$, and $\left.2,250 \mathrm{mg} \mathrm{kg}^{-1}\right)$ and $\mathrm{P}_{2} \mathrm{O}_{5}$ $\left(0 ; 41.7 ; 83.4\right.$, and $\left.125.1 \mathrm{mg} \mathrm{kg}^{-1}\right)$, with a $4 \times 4$ factorial arrangement, in a completely randomized design with four replications. Morphological variables and nutritional content taken at 165 days after transplant were shown to be adequate to assess the initial growth and to show their nutritional requirements, indicating that plants are responsive to phosphorus. The association of higher gypsum and $\mathrm{P}_{2} \mathrm{O}_{5}$ levels promoted higher plant vigor and their application to the soil increased the availability of calcium, phosphorus, and base saturation.
\end{abstract}

Keywords: Brazilian pepper tree, nutritional requirements, dystrophic red latosol, leaching column.

\section{INTRODUCTION AND OBJECTIVES}

The nutritional requirements of native species are different from undemanding species to others, on which growth is totally limited in the absence of nutrients. Such factors hinder the choice of foresters to invest in planting native species, because the agronomic information, especially the nutritional ones, are still not accurate. Therefore, studies aiming to clarify these information are essential for increasing the diversity of native tree species implanted in forestry.

The Brazilian pepper tree (Schinus terebinthifolius Raddi, Anacardiaceae), naturally found in Brazil, presents high ecological plasticity (Dawkins \& Esiobu, 2016). The hybrid form of the Brazilian pepper tree, found in the United States, presents growth and longevity even larger than the native trees found in South America (Geiger et al., 2011). It is important for both ecological and economic purposes. Worldwide, the species is also known as pink pepper or baies roses because its fruit has a very appreciated flavor in the market. Besides its food properties, the Brazilian pepper tree also has medicinal properties (Johann et al., 2010). It is indicated in reforestation programs, serving as shader of late secondary and climax species; moreover, its fruit also serves as food for birds (Andrade \& Boaretto, 2012).

In Brazilian soils, acidity and high levels of aluminum content are common, both on the surface and on the deeper layers of the soil. With low cation exchange capacity and nutrient availability in these highly weathered soils (Eberhardt et al., 2008), 1:1 clay minerals with high phosphorus adsorption capacity predominate, such as kaolinite, iron $(\mathrm{Fe})$, and $\mathrm{Al}$ oxides (Carnevali et al., 2016). The use of agricultural gypsum is recommended to improve the root environment in many cases, reducing the toxicity of $\mathrm{Al}^{3+}$ to the plants and providing cations in depth (Rampim et al., 2011; Ramos et al., 2013).

\footnotetext{
${ }^{1}$ Universidade Federal do Sul e Sudeste do Pará (Unifesspa), São Félix do Xingu, PA, Brasil

${ }^{2}$ Universidade Federal da Grande Dourados (UFGD), Dourados, MS, Brasil

${ }^{3}$ Universidade Federal do Pará (UFPA), Altamira, PA, Brasil

${ }^{4}$ Universidade Estadual do Mato Grosso do Sul (UEMS), Dourados, MS, Brasil
} 
However, because of the lack of studies with native species, there are still doubts about the conditions on which favorable effects of gypsum can be expected and how to recommend the product, which is only used as a complement to fertilization as in the study performed by Alves \& Souza (2008).

Information about the nutritional requirements of the Brazilian pepper tree is still limited, complicating recommendations for its cultivation. Therefore, our study aimed to verify the effect of agricultural gypsum and phosphorus in the initial development of the Brazilian pepper tree and its effects on soil fertility.

\section{MATERIALS AND METHODS}

This study was performed in a protected environment from August 2011 to January 2012, in Dourados (Mato Grosso do Sul State), which has the following geographical coordinates: $22^{\circ} 11^{\prime} 53.52^{\prime \prime}$ South and $54^{\circ} 56^{\prime} 2.25^{\prime \prime}$ West, and altitude of $461 \mathrm{~m}$. The climate is tropical with dry winter (Aw), according to the Köppen climate classification, while the average temperature is $23.6^{\circ} \mathrm{C}$.

The Brazilian pepper tree fruits, sampled in Dourados $\left(22^{\circ} 11^{\prime} 43.30^{\prime \prime} \mathrm{S}\right.$ and $\left.54^{\circ} 56^{\prime} 8.67^{\prime \prime} \mathrm{W}\right)$, were manually macerated for seed removal and then seeded in polystyrene trays with Bioplant ${ }^{\circ}$ agricultural substrate. The seedlings were maintained at $50 \%$ shading and irrigated daily until they were approximately $10 \mathrm{~cm}$ high.

Soil samples were collected from an Oxisol (Dystroferric Red Latosol), classified as a dystrophic Red Latosol (Oxisol) of clayey texture (Santos et al., 2013). They were collected at the Bw horizon and were chemically (Silva et al., 2009) and physically (Donagema et al., 2011) characterized. The soil had the following characteristics: $\mathrm{pH}_{\text {water }}=4.5 ; \mathrm{pH}\left(\mathrm{CaCl}_{2}\right)=4.2$; Organic Matter $(\mathrm{OM})=8.0 \mathrm{~g} \mathrm{~kg}^{-1} ; \mathrm{P}=1.1 \mathrm{cmol}_{\mathrm{c}} \mathrm{dm}^{-3}$ (Mehlich 1); $\mathrm{K}=0.05 \mathrm{cmol}_{c} \mathrm{dm}^{-3}$ (Mehlich 1); $\mathrm{Ca}=0.4 \mathrm{cmol} \mathrm{dm}_{c}^{-3}$; $\mathrm{Mg}=0.2 \mathrm{cmol}_{c} \mathrm{dm}^{-3} ; \mathrm{Al}=1.4 \mathrm{cmol} \mathrm{dm}_{c}^{-3} ; \mathrm{H}+\mathrm{Al}=7.6 \mathrm{cmol} \mathrm{dm}_{c}^{-3} ;$ $\mathrm{SB}=0.65 \mathrm{cmol}_{\mathrm{c}} \mathrm{dm}^{-3} ; \mathrm{T}=8.2 \mathrm{cmol}_{\mathrm{c}} \mathrm{dm}^{-3} ; \mathrm{V} \%=7.9$; $\mathrm{Cu}=5.2 \mathrm{mg} \mathrm{dm}^{-3} ; \mathrm{Mn}=3.6 \mathrm{mg} \mathrm{dm}^{-3} ; \mathrm{Fe}=38.2 \mathrm{mg} \mathrm{dm}^{-3}$; $\mathrm{Zn}=0.7 \mathrm{mg} \mathrm{dm}^{-3}$; Clay $=644 \mathrm{~g} \mathrm{~kg}^{-1}$, silt $=203 \mathrm{~g} \mathrm{~kg}^{-1}$ and sand $=153 \mathrm{~g} \mathrm{~kg}^{-1}$.

The treatments consisted of four doses of agricultural gypsum $\left(0 ; 750 ; 1,500\right.$, and $2,250 \mathrm{mg} \mathrm{kg}^{-1}$, corresponding to $0 ; 1,200 ; 2,400$, and $\left.3,600 \mathrm{~kg} \mathrm{ha}^{-1}\right)$ and four doses of $\mathrm{P}_{2} \mathrm{O}_{5}(0 ; 41.7$; 83.4 , and $125.1 \mathrm{mg} \mathrm{kg}^{-1}$, corresponding to $0 ; 100 ; 200$, and $300 \mathrm{~kg} \mathrm{ha}^{-1}$, triple superphosphate source) with a $4 \times 4$ factorial arrangement in a completely randomized design with four replications. The study was performed in leach columns of $150 \mathrm{~mm}$ diameter $\times 60 \mathrm{~cm}$ height, divided into six $10 \mathrm{~cm}$ rings.

The columns were filled with soil samples sieved in a $4 \mathrm{~mm}$ mesh and compacted to reach density of $1.1 \mathrm{Mg} \mathrm{m}^{-3}$.
The compaction was performed only in the $20-60 \mathrm{~cm}$ layers, aiming to simulate soil density and tillage conditions in conventional crops. Liming, doses of gypsum and $\mathrm{P}_{2} \mathrm{O}_{5}$, as well as other nutrients, were applied and incorporated only in the $0-10 \mathrm{~cm}$ layer. To increase the base saturation to $60 \%$, dolomitic limestone with $100 \%$ total neutralizing power was used, manually incorporated 30 days before transplantation. Additional fertilization was also performed with $62.5 \mathrm{mg} \mathrm{kg}^{-1}$ of $\mathrm{N}$ (urea source), divided into two applications, $25 \mathrm{mg} \mathrm{kg}^{-1} \mathrm{~K}_{2} \mathrm{O}$ (source $\mathrm{KCl}$ ) and $100 \mathrm{mg}$ $\mathrm{kg}^{-1}$ of commercial FTE-BR12 micronutrient formulation, applied five days before transplantation. Each column was internally coated with a plastic bag to prevent loss of water and nutrients by drainage. Irrigation was performed every two days.

The experiment was performed for 165 days in a protected environment with transparent polyethylene cover and 50\% shade side cloth. The following variables were analyzed at harvest: plant height $(\mathrm{cm})$; stem diameter $(\mathrm{mm})$; leaf area $\left(\mathrm{cm}^{2}\right)$, which was estimated using Windias image analyzer (Windias, Delta-T Devices, Cambrigde, UK); and dry weight (g) of the shoot and the root. From the morphological data, the leaf area ratio and the Dickson Quality Index (Dickson et al., 1960) were estimated.

Macronutrient contents in the shoot were quantified according to the method of Malavolta et al. (1997) and transformed into content by the product with shoot dry weight. The following aspects from the soil samples were assessed: $\mathrm{pH}_{\text {water }}$ and $\mathrm{CaCl}_{2} ; \mathrm{P}$ and $\mathrm{K}$ extracted by Mehlich one solution; $\mathrm{Ca}, \mathrm{Mg}$, and $\mathrm{Al}$ extracted with $\mathrm{KCl}\left(1.0 \mathrm{~mol} \mathrm{~L}^{-1}\right)$; $\mathrm{S}-\mathrm{SO}_{4}^{2-}$, extracted by phosphate ions dissolved in acetic acid (2.0 $\left.\mathrm{mol} \mathrm{L}^{-1}\right) ; \mathrm{H}+\mathrm{Al}$; Sum of bases (SB); cation exchange capacity (CEC), and base saturation (V\%), according to Silva et al. (2009).

The data were submitted to analysis of variance, and a regression and/or a Tukey test was performed at a 5\% probability for the significant factors.

\section{RESULTS AND DISCUSSION}

\subsection{Plant development and quality}

There was a significant effect of gypsum and $\mathrm{P}_{2} \mathrm{O}_{5}$ interaction for all morphological parameters and relationships assessed. The highest doses of gypsum and $\mathrm{P}_{2} \mathrm{O}_{5}$ provided the highest height value $(61.8 \mathrm{~cm})$, while the largest diameter of the stem was obtained with the highest $\mathrm{P}_{2} \mathrm{O}_{5}$ dose $(9.36 \mathrm{~mm})$, as shown in Figures 1a and 1b, respectively. 


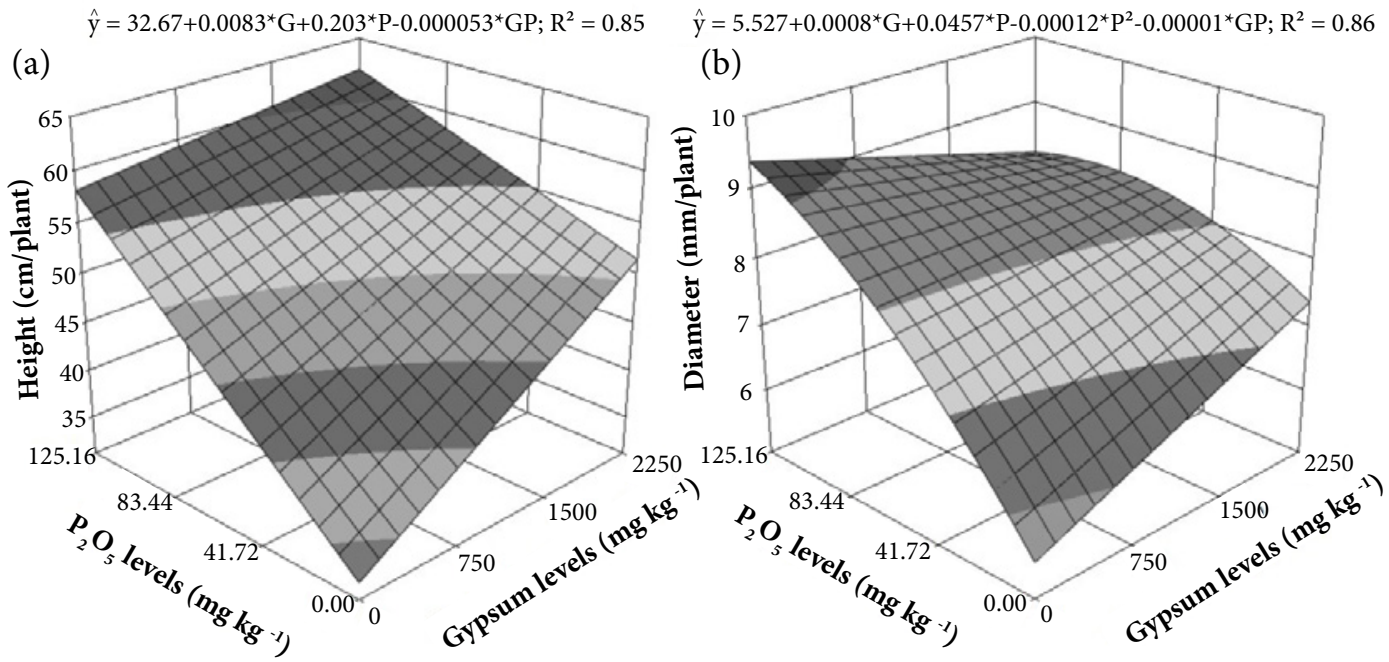

Figure 1. Plant height (a) and stem diameter (b) of Brazilian pepper tree at 165 days after transplantation by different gypsum and $\mathrm{P}_{2} \mathrm{O}_{5}$ levels. * Significant at $5 \%$ by t-test.

The benefits of the joint application of gypsum and $\mathrm{P}_{2} \mathrm{O}_{5}$ were evident in the Brazilian pepper tree growth. The high $\mathrm{N}$ and S-SO ${ }_{4}^{2-}$ levels in the shoot, shown in Table 1, contributed to stimulate the vegetative growth, increasing leaf bud production. Andrade \& Boaretto (2012) also observed high $\mathrm{N}$ and S levels in Brazilian pepper tree shoots, in which were observed $13 \mathrm{~g} \mathrm{~kg}^{-1}$ of $\mathrm{N}$ ( $572 \mathrm{mg} /$ plant of $\mathrm{N}$ ) and $1.95 \mathrm{~g} \mathrm{~kg}^{-1}$ of $\mathrm{S}(85.8 \mathrm{mg} / \mathrm{plant}$ of $\mathrm{S})$ in complete nutrient solution.

The higher gypsum and $\mathrm{P}_{2} \mathrm{O}_{5}$ levels also provided a higher leaf area $\left(1,023.7 \mathrm{~cm}^{2}\right)$. However, the leaf area ratio was lower $\left(31.46 \mathrm{~cm}^{2} \mathrm{~g}^{-1}\right)$ in the absence of gypsum and with the higher $\mathrm{P}_{2} \mathrm{O}_{5}$ dose, as shown in Figures 2a and 2b, respectively. This indicates that with higher phosphorus supply, the plant needs a smaller leaf area for biomass production.

The growth of leaf area determines the interception of light and is an important parameter to determine the plant yield (Koester et al., 2014). However, the relation between leaf area growth and mass growth will depend on how carbon is partitioned in increasing leaf area, total plant growth, reproduction, and respiration (Weraduwage et al., 2015). According to these authors, the use of the relationship between growth and leaf area is more appropriate at the beginning of the vegetative growth. Thus, in this study, the leaf area ratio was an important parameter to confirm that the Brazilian pepper tree has good responses to phosphorus in the initial growth stages.

The highest dry weights of shoot (18.2 g) and root (6.8 g) were obtained with the highest gypsum and $\mathrm{P}_{2} \mathrm{O}_{5}$ levels, according to Figure 3 . The Brazilian pepper tree response to $\mathrm{P}$ (phosphorus) was high. The same result was also found for Santos et al. (2008), where $800 \mathrm{mg} \mathrm{dm}^{-3}$ of P were not enough to provide maximum biomass accumulation. At 90 days in this condition, the plants showed $51.9 \mathrm{~g}$ dry shoot weight, an increase of $250 \%$, compared to the zero dose. It is worth mentioning that in this study the use of gypsum with phosphorus increased the dry weight gain in $13.2 \%$ for root and $13.6 \%$ for shoot.

Table 1. Macronutrients content (mg/plant) of Brazilian pepper tree shoot at 165 days after transplantation by different gypsum and $\mathrm{P}_{2} \mathrm{O}_{5}$ levels.

\begin{tabular}{|c|c|c|c|c|c|}
\hline Nutrient & Regression equation & $\mathbf{R}^{2}$ & $P$ levels & $\begin{array}{l}\text { Gypsum } \\
\text { levels }\end{array}$ & $\begin{array}{l}\text { Maximum } \\
\text { value }\end{array}$ \\
\hline $\mathrm{N}$ & $\hat{\mathrm{y}}=\mathbf{1 0 9 . 1 2 4}+0.0322 * \mathrm{G}+1.602 * \mathrm{P}-0.006 * \mathrm{P}^{2}$ & 0.60 & 125.1 & 2,250 & 288.1 \\
\hline $\mathrm{P}$ & $\hat{\mathrm{y}}=41.5102+0.0178^{\star} \mathrm{G}+0.3231 * \mathrm{P}$ & 0.62 & 125.1 & 2,250 & 121.9 \\
\hline $\mathrm{K}$ & $\hat{\mathrm{y}}=69.77+0.046^{\star} \mathrm{G}+1.134{ }^{\star} \mathrm{P}-0.0035^{\star} \mathrm{P}^{2}-0.003 * \mathrm{GP}$ & 0.61 & 66.7 & 2,250 & 188.0 \\
\hline $\mathrm{Ca}$ & $\hat{y}=37.504+0.0146 * G+0.896 * P-0.0039 * P^{2}$ & 0.75 & 125.1 & 2,250 & 121.4 \\
\hline $\mathrm{Mg}$ & $\hat{\mathbf{y}}=\mathbf{1 2 . 2 5}+0.0043^{\star} \mathrm{G}+0.113{ }^{\star} \mathrm{P}$ & 0.74 & 125.1 & 2,250 & 36 \\
\hline S & $\hat{y}=63.68+0.054 G+3.09 * P-0.0102 P^{2}-0.00036 G P$ & 0.60 & 125.1 & 2,250 & 312.6 \\
\hline
\end{tabular}

* Significant at $5 \%$ by t-test. 


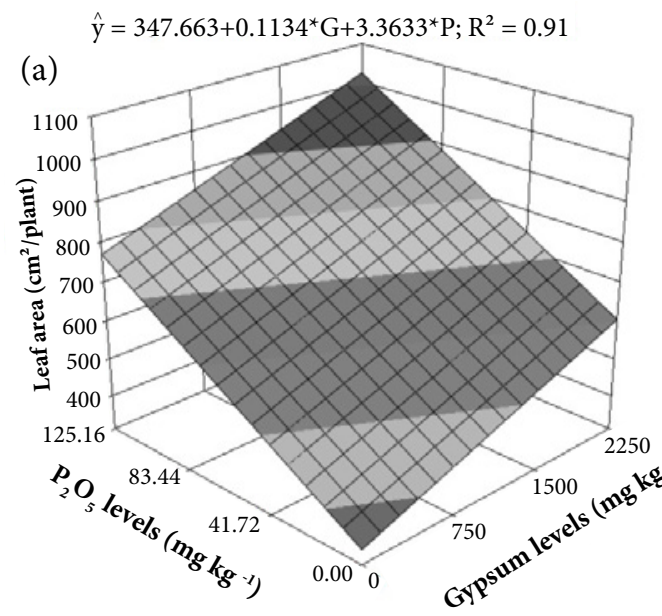

$\hat{\mathrm{y}}=49.54+0.0048^{\star} \mathrm{G}-0.01445^{\star} \mathrm{P}+0.000062^{\star} \mathrm{GP} ; \mathrm{R}^{2}=0.58$

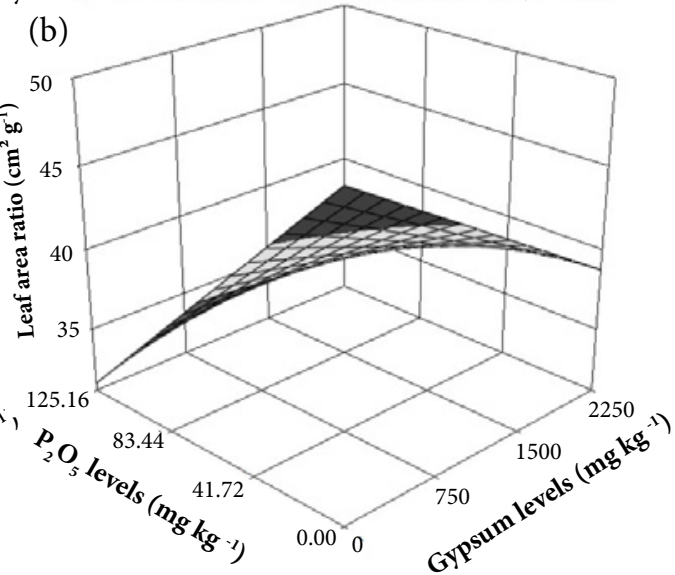

Figure 2. Leaf area (a) and leaf area ratio (b) of Brazilian pepper tree at 165 days after transplantation by different gypsum and $\mathrm{P}_{2} \mathrm{O}_{5}$ levels.

* Significant at $5 \%$ by $\mathrm{t}$-test.
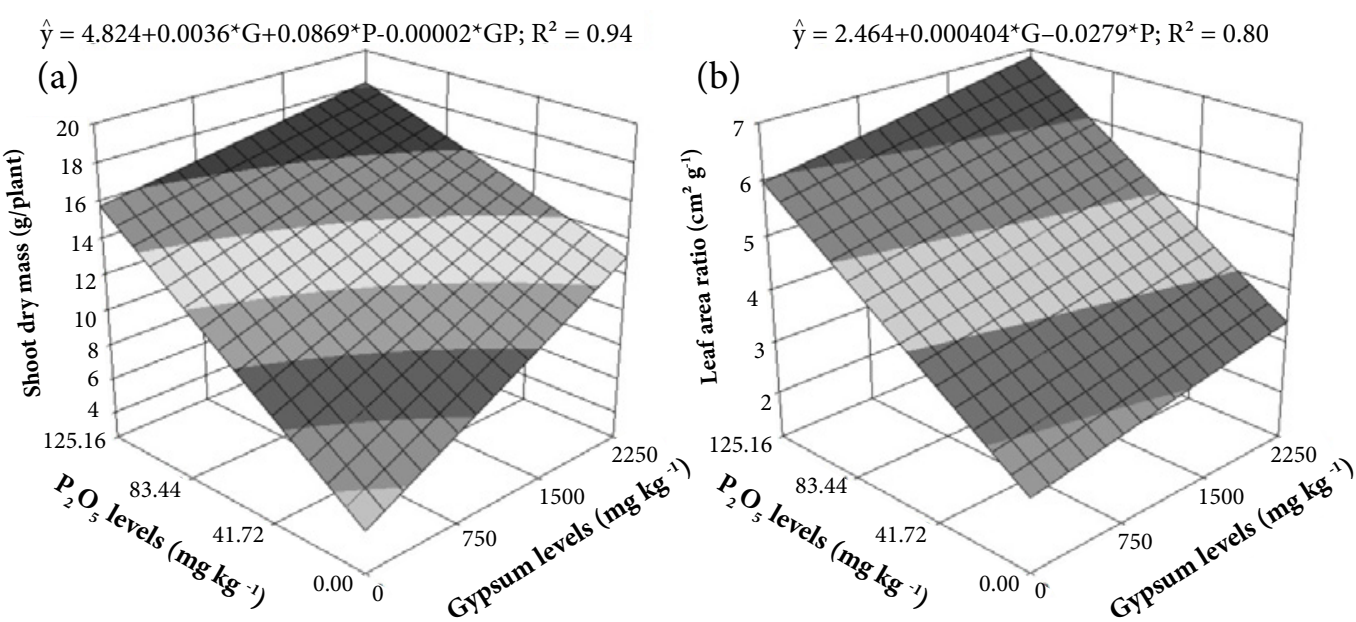

Figure 3. Shoot (a) and root (b) dry weight of Brazilian pepper tree at 165 days after transplantation by different gypsum and $\mathrm{P}_{2} \mathrm{O}_{5}$ levels.

${ }^{*}$ Significant at $5 \%$ by t-test.

The distribution of roots in deeper layers of the soil was favored by the increasing gypsum levels, which mitigated the differences between treatments that did not receive $\mathrm{P}_{2} \mathrm{O}_{5}$, as shown in Table 2. The best root growth in the presence of gypsum may be associated to the increase of $\mathrm{Ca}$ and $\mathrm{S}_{-} \mathrm{SO}_{4}{ }^{2-}$ content in the soil, as shown in Table 3.

Table 2. Root dry weight distribution of the Brazilian pepper tree at each depth, at 165 days after transplantation by the interaction between different doses of gypsum and $\mathrm{P}_{2} \mathrm{O}_{5}$.

\begin{tabular}{cccccccc} 
Levels & \multicolumn{5}{c}{ Depth $(\mathbf{c m})$} \\
\cline { 2 - 7 }$(\mathbf{G} \times \mathbf{P})$ & $\mathbf{0 - 1 0}$ & $\mathbf{1 0 - 2 0}$ & $\mathbf{2 0 - 3 0}$ & $\mathbf{3 0 - 4 0}$ & $\mathbf{4 0 - 5 0}$ & $\mathbf{5 0 - 6 0}$ \\
\hline $0 \times 0$ & $0.809 \mathrm{Ag}$ & $0.173 \mathrm{Bh}$ & $0.078 \mathrm{Bc}$ & $0.052 \mathrm{Bc}$ & $0.046 \mathrm{Ba}$ & $0.059 \mathrm{Ba}$ \\
$0 \times 41.7$ & $3.047 \mathrm{Ad}$ & $0.687 \mathrm{Bcde}$ & $0.401 \mathrm{Cab}$ & $0.269 \mathrm{DEabc}$ & $0.175 \mathrm{Da}$ & $0.092 \mathrm{Ea}$ \\
\hline $0 \times 83.4$ & $3.127 \mathrm{Ad}$ & $0.435 \mathrm{Befgh}$ & $0.262 \mathrm{CDbc}$ & $0.202 \mathrm{Dabc}$ & $0.162 \mathrm{Da}$ & $0.113 \mathrm{DEa}$ \\
\hline $0 \times 125.1$ & $3.787 \mathrm{Ab}$ & $0.725 \mathrm{Bbcd}$ & $0.403 \mathrm{Cab}$ & $0.230 \mathrm{CDabc}$ & $0.190 \mathrm{CDa}$ & $0.169 \mathrm{Da}$ \\
\hline
\end{tabular}


Table 2. Continued...

\begin{tabular}{|c|c|c|c|c|c|c|}
\hline \multirow{2}{*}{$\begin{array}{l}\text { Levels } \\
(G \times P)\end{array}$} & \multicolumn{6}{|c|}{ Depth $(\mathrm{cm})$} \\
\hline & $0-10$ & $10-20$ & $20-30$ & $30-40$ & $40-50$ & $50-60$ \\
\hline $750 \times 0$ & $2.061 \mathrm{Af}$ & $0.253 \mathrm{Bh}$ & $0.182 \mathrm{Bbc}$ & $0.181 \mathrm{Babc}$ & $0.146 \mathrm{Ba}$ & $0.101 \mathrm{Ba}$ \\
\hline $750 \times 41.7$ & $3.239 \mathrm{Acd}$ & $0.336 \mathrm{Bgh}$ & $0.258 \mathrm{Bbc}$ & $0.223 \mathrm{Babc}$ & $0.163 \mathrm{Ba}$ & $0.147 \mathrm{Ba}$ \\
\hline $750 \times 83.4$ & $3.829 \mathrm{Ab}$ & $1.029 \mathrm{Ba}$ & $0.581 \mathrm{Ca}$ & $0.406 \mathrm{Cda}$ & $0.208 \mathrm{Da}$ & $0.145 \mathrm{Ea}$ \\
\hline $750 \times 125.1$ & $4.324 \mathrm{Aa}$ & $0.975 \mathrm{Bab}$ & $0.666 \mathrm{Ca}$ & $0.340 \mathrm{Dab}$ & $0.231 \mathrm{Da}$ & $0.221 \mathrm{Da}$ \\
\hline $1,500 \times 0$ & $1.905 \mathrm{Af}$ & $0.372 \mathrm{Bfgh}$ & $0.192 \mathrm{CDbc}$ & $0.154 \mathrm{CDbc}$ & $0.126 \mathrm{Da}$ & $0.112 \mathrm{Da}$ \\
\hline $1,500 \times 41.7$ & $2.354 \mathrm{Ae}$ & $0.329 \mathrm{Bgh}$ & $0.242 \mathrm{Bbc}$ & $0.190 \mathrm{Babc}$ & $0.144 \mathrm{Ba}$ & $0.141 \mathrm{Ba}$ \\
\hline $1,500 \times 83.4$ & $3.947 \mathrm{Ab}$ & $1.012 \mathrm{Ba}$ & $0.431 \mathrm{Cab}$ & $0.369 \mathrm{CDab}$ & $0.244 \mathrm{Ca}$ & $0.182 \mathrm{Da}$ \\
\hline $1,500 \times 125.1$ & $3.494 \mathrm{Ac}$ & $0.950 \mathrm{Babc}$ & $0.607 \mathrm{Ca}$ & $0.363 \mathrm{Dab}$ & $0.243 \mathrm{Da}$ & $0.229 \mathrm{Da}$ \\
\hline $2,250 \times 0$ & $2.619 \mathrm{Ae}$ & $0.352 \mathrm{Bfgh}$ & $0.228 \mathrm{Bbc}$ & $0.213 \mathrm{Babc}$ & $0.208 \mathrm{Ba}$ & $0.202 \mathrm{Ba}$ \\
\hline $2,250 \times 41.7$ & $3.141 \mathrm{Ad}$ & 0.552 Bdefg & $0.287 \mathrm{Cbc}$ & $0.218 \mathrm{Cabc}$ & $0.146 \mathrm{Ca}$ & $0.137 \mathrm{Ca}$ \\
\hline $2,250 \times 83.4$ & $3.931 \mathrm{Ab}$ & 0.617 Bdef & $0.445 \mathrm{BCab}$ & $0.314 \mathrm{CDabc}$ & $0.203 \mathrm{Da}$ & $0.168 \mathrm{Da}$ \\
\hline $2,250 \times 125.1$ & $3.876 \mathrm{Ab}$ & $1.013 \mathrm{Ba}$ & $0.648 \mathrm{Ca}$ & $0.354 \mathrm{Dab}$ & $0.260 \mathrm{Da}$ & $0.242 \mathrm{Da}$ \\
\hline
\end{tabular}

Means followed by the same letter, uppercase in the same row, and lowercase in the same column, do not differ by Tukey's test at a $5 \%$ probability level. Gypsum and $\mathrm{P}_{2} \mathrm{O}_{5}$ levels in $\mathrm{mg} \mathrm{kg}^{-1}$.

The highest value of the Dickson index (2.52) was obtained at higher gypsum and $\mathrm{P}_{2} \mathrm{O}_{5}$ levels, indicating higher plant quality, according to Figure 4. This index is an important parameter for the assessment of the Brazilian pepper tree quality, as it considers the balance of biomass distribution. The Brazilian pepper tree shows high growth response when fertilized with phosphorus; moreover, gypsum increases the availability of $\mathrm{Ca}$ and $\mathrm{S}$ and, therefore, it promotes improvements in absorption of nutrients.

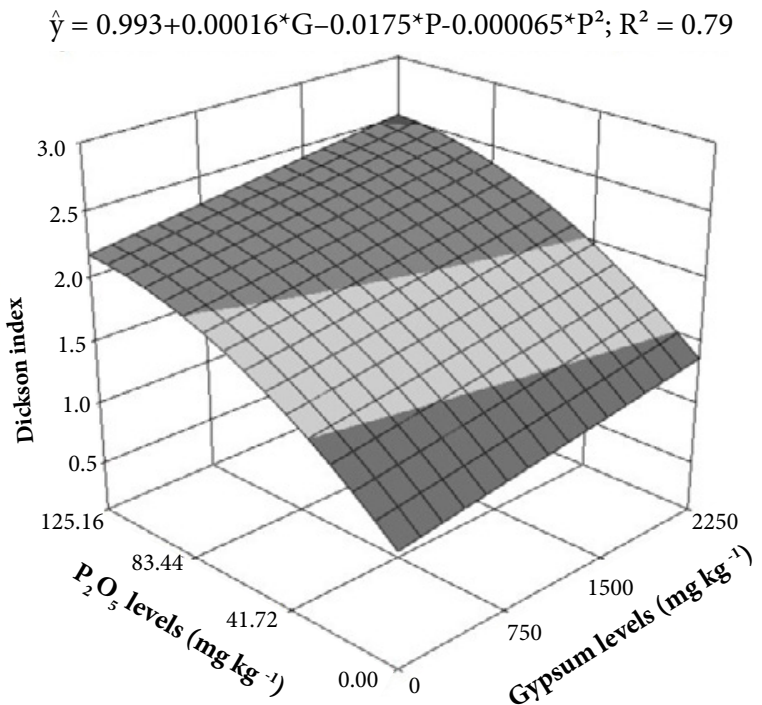

Figure 4. Dickson index of the Brazilian pepper tree at 165 days after transplantation by gypsum and $\mathrm{P}_{2} \mathrm{O}_{5}$ levels.

${ }^{*}$ Significant at $5 \%$ by $\mathrm{t}$-test.

\subsection{Soil chemical characteristics}

The levels of $\mathrm{P}, \mathrm{Al}^{3+}, \mathrm{H}+\mathrm{Al}$, and $\mathrm{pH}_{\text {water }}$ were significantly altered by depth effect, as shown in Table 3 . The $\mathrm{Al}^{3+}$ content showed the maximum point at $42.8 \mathrm{~cm}$ depth; at the same depth, the $\mathrm{P}$ content presented the minimum point $\left(1.13 \mathrm{mg} \mathrm{dm}^{-3}\right)$. On the other hand, the potential acidity decreased in depth, from $13.9 \mathrm{cmol}_{c} \mathrm{dm}^{-3}$ in the $0-10 \mathrm{~cm}$ layer to $13.4 \mathrm{cmol}_{c} \mathrm{dm}^{3}$ at $60 \mathrm{~cm}$. At $37.6 \mathrm{~cm}$ depth, the soil $\mathrm{pH}_{\text {water }}$ had the minimum point of 4.59 .

The vertical displacement of fine limestone particles, and consequently their chemical mobilization in subsurface, can reduce the effects of acidity, even in a short period (Amaral et al., 2004), which would explain the reduction in $\mathrm{Al}^{3+}$ and $\mathrm{H}+\mathrm{Al}$ contents and the increase in $\mathrm{pH}$ and $\mathrm{P}$ levels at depths greater than $40 \mathrm{~cm}$. At the same depths, where the acidity and the $\mathrm{Al}^{3+}$ contents are higher, $\mathrm{P}$ content was reduced, possibly because of adsorption reactions, which naturally occur with Fe oxides, such as goethite and hematite (Lü et al., 2017).

There was vertical displacement of soil particles, such as $\mathrm{Ca}, \mathrm{S}, \mathrm{K}$, as well as base sum and base saturation, with few effects regarding gypsum and phosphorus. The direct effects of gypsum applications in depth were only observed for the $\mathrm{Ca}$ and $\mathrm{S}$ content, according to Table 3 , in which there were minimum points for the Ca content $\left(0.73 \mathrm{cmol}_{\mathrm{c}} \mathrm{dm}^{-3}\right)$ at $43.9 \mathrm{~cm}$ and for sulfur $\left(14.1 \mathrm{cmol}_{\mathrm{c}} \mathrm{dm}^{-3}\right)$ at $37.5 \mathrm{~cm}$. As gypsum is more soluble than limestone, it promotes a fast $\mathrm{Ca}$ availability in the soil, especially in the superficial layers (Soratto \& Crusciol, 2008). On the other hand, the S-SO ${ }_{4}^{-2}$ 
anion movement is favored by its cation binding capacity, forming null charge molecules that ease the descent into the soil profile (Cremon et al., 2009). However, the higher the gypsum amount applied to the soil, the greater the permanence of $\mathrm{S}_{-} \mathrm{SO}_{4}^{-2}$ and $\mathrm{Ca}$ in the surface layers. It possibly happens because of high iron and oxides levels in the soil, which have high anion retention capacity, hindering the movement in the profile.

Table 3. Soil chemical attributes after 165 days of experiment by the depth effect and the interaction between depth and levels of gypsum and $\mathrm{P}_{2} \mathrm{O}_{5}$.

\begin{tabular}{|c|c|c|}
\hline Element & Regression equation & $\mathbf{R}^{2}$ \\
\hline \multicolumn{3}{|c|}{ Depth } \\
\hline $\mathrm{Al}^{3+}$ & $\hat{y}=-0.95+0.12 * D-0.0014 * D^{2}$ & 0.92 \\
\hline $\mathrm{P}$ & $\hat{y}=2.01-0.041 * D+0.0005^{*} D^{2}$ & 0.83 \\
\hline $\mathrm{H}+\mathrm{Al}$ & $\hat{y}=13.9-0.0073 * D$ & 0.81 \\
\hline $\mathrm{pH}$ & $\hat{y}=5.63-0.055^{*} \mathrm{D}+0.00073 * \mathrm{D}^{2}$ & 0.90 \\
\hline \multicolumn{3}{|c|}{ Depth and gypsum } \\
\hline $\mathrm{Ca}$ & $\hat{y}=6.78-0.29 * D+0.0033 * D^{2}+0.00014 * G$ & 0.85 \\
\hline S & $\hat{y}=14.56-0.03 * D+0.0004 * D^{2}+0.0003 * G-0.000007 * D G$ & 0.77 \\
\hline \multicolumn{3}{|c|}{ Depth and P2O5 } \\
\hline K & $\hat{y}=3.92-0.12 * D+0.0013 * D^{2}-0.0076^{\star} P+0.00022 * D P$ & 0.70 \\
\hline S & $\hat{y}=14.92-0.03 * D+0.004 * D^{2}+0.0001 P+0.000005^{*} D P$ & 0.88 \\
\hline SB & $\hat{y}=15.2-0.59 * D+0.006^{\star} D^{2}-0.007 P+0.0001 D P$ & 0.84 \\
\hline $\mathrm{V} \%$ & $\hat{y}=57.9-1.93 * D+0.02 * D^{2}-0.02 * P+0.0005 D P$ & 0.86 \\
\hline \multicolumn{3}{|c|}{ Gypsum and P2O5 } \\
\hline $\mathrm{P}$ & $\hat{y}=1.114-0.000007 G+0.00000004 G^{2}+0.0034 * P-0.0000008 G P$ & 0.61 \\
\hline $\mathrm{Ca}$ & $\hat{y}=1.97-0.0002 G+0.0000001 G^{2}-0.004 * P+0.000002 * G P$ & 0.59 \\
\hline $\mathrm{V} \%$ & $\hat{y}=25.04-0.002 * G+0.000001 * G^{2}-0.02 * P+0.00001 * G P$ & 0.53 \\
\hline
\end{tabular}

* Significant at $5 \%$ by t-test. D: depth; G: gypsum; $\mathrm{P}: \mathrm{P}_{2} \mathrm{O}_{5}$.

In the interaction between phosphorus and depth, the $\mathrm{K}$ content had the minimum point $\left(1.57 \mathrm{cmol}_{\mathrm{c}} \mathrm{dm}^{-3}\right)$ at $40.7 \mathrm{~cm}$, as shown in Table 3 . From this point, the $\mathrm{K}$ content increases, reaching the maximum $\left(2.45 \mathrm{cmol}_{c} \mathrm{dm}^{-3}\right)$ at $60 \mathrm{~cm}$ with the highest level of $\mathrm{P}_{2} \mathrm{O}_{5}$. The sum of base showed the same pattern in depth, reaching $2.35 \mathrm{cmol}_{c} \mathrm{dm}^{-3}$ at $49 \mathrm{~cm}$, according to Table 3 . The fertilizers addition to soil affects the availability and permanence of other elements in the soil, even temporarily (Ernani et al., 2007), confirmed by the $\mathrm{K}$ content reduction with the increasing of phosphate fertilization in the superficial layers. Nonetheless, unlike Akinremi \& Cho (1993) observed in their study, the phosphorus addition did not reduce the $\mathrm{K}$ percolation at deeper layers. On the contrary, the higher the level of phosphorus, the greater the $\mathrm{K}$ losses by leaching. The same was observed to the sum of bases. The $\mathrm{Ca}^{2+}, \mathrm{Mg}^{2+}$, and $\mathrm{K}^{+}$exchangeable cations of the soil have different retention energies to soil colloids, following the lyotropic series (Werle et al., 2008). $\mathrm{K}^{+}$has lower energy retention, because it is a monovalent cation. This results in higher leaching levels in well-drained soils, especially in soils with lower cation exchange capacity.
This partly explains why the $\mathrm{K}$ and sum of base reduced until a certain depth level.

There was also a significant interaction between gypsum and $\mathrm{P}_{2} \mathrm{O}_{5}$ doses, for $\mathrm{Ca}$ and $\mathrm{P}$ contents as well as for base sum, as shown in Table 3. The highest doses promoted maximum Ca content in the soil $\left(2.2 \mathrm{cmol} \mathrm{dm}^{-3}\right)$ and also increased $\mathrm{P}$ content in the soil. However, the $\mathrm{P}_{2} \mathrm{O}_{5}$ doses increase was more favorable than its application with gypsum, increasing from 1.1 to $1.5 \mathrm{mg} \mathrm{dm}^{-3}$ the $\mathrm{P}$ content in the soil. In the fraction clay of the Savanna Brazilian Oxisols (Latosols) there are oxides of iron and aluminum, which strongly adsorb the phosphorus. Under these conditions, high phosphate application fertilizer is required to increase plant availability. Santos et al. (2008) verified that the Brazilian pepper tree showed high phosphorus use efficiency, even in the absence of fertilization, which explains satisfactory growth even at low doses. These results indicate the species is adapted, because of its high plasticity to the low fertility conditions of the soil.

The sum of base and the $\mathrm{S}_{-} \mathrm{SO}_{4}^{2-}$ showed similar behavior to the interaction between $\mathrm{P}_{2} \mathrm{O}_{5}$ doses and depth, with the minimum point between depths of 37.5 and $48.2 \mathrm{~cm}$, respectively. Because 
of the high binding strength of the phosphates to the colloids, especially in clayey soils (Raij, 1991), it is expected that greater sulfate losses occur in depth. In this sense, it is necessary to consider the leaching of bases and sulfate when combining these inputs. The splitting of the recommended gypsum dose may be the solution to avoid nutrients loss under field conditions.

\section{CONCLUSION}

The use of morphological variables and their relationships are adequate to assess the initial growth of the Brazilian pepper tree and show its nutritional needs.

The gypsum is an important conditioner of the soil, and therefore, it can be indicated as a complement to the Brazilian pepper tree fertilization.

The association of gypsum and $\mathrm{P}_{2} \mathrm{O}_{5}$ is beneficial and favors higher quality of plants.

The Brazilian pepper tree is not demanding in phosphorus; however, it is very responsive to it.

An adequate management is crucial in order to produce Brazilian pepper tree with commercial purposes, as phosphate fertilization is essential to develop the vegetative characteristics that will later benefit fruit production.

The application of agricultural gypsum favored improvements in the chemical characteristics of the soil, increasing the availability of some nutrients.

\section{ACKNOWLEDGEMENTS}

We thank the Coordenação de Aperfeiçoamento de Pessoal de Nível Superior (Capes) for granting scholarships and the Conselho Nacional de Desenvolvimento Científico e Tecnológico (CNPq) for the financial support for research projects.

\section{SUBMISSION STATUS}

Received: 20 Dec. 2017

Accepted: 16 Apr. 2019

Associate editor: Marcos Gervásio Pereira

0000-0002-1402-3612

\section{CORRESPONDENCE TO Natália Hilgert de Souza Carnevali}

Universidade Federal do Sul e Sudeste do Pará (Unifesspa), Rua Constantino Ferreira Viana, s/n, quadra 8, Centro, CEP 68380-000, São Félix do Xingu, PA, Brasil

e-mail: nataliahilgert@unifesspa.edu.br

\section{FINANCIAL SUPPORT}

Ministério da Ciência, Tecnologia e Inovação, Conselho Nacional de Desenvolvimento Científico e Tecnológico (CNPq); Coordenação de Aperfeiçoamento de Pessoal de Nível Superior (Capes).

\section{REFERENCES}

Akinremi OO, Cho CM. Phosphorus diffusion retardation in a calcareous system by coapplication of potassium chloride. Soil Science Society of America Journal 1993; 57(3): 845-850.

Alves MC, Souza ZM. Recuperação de área degradada por construção de hidrelétrica com adubação verde e corretivo. Revisa Brasileira da Ciência do Solo 2008; 32(6): 2505-2516. 10.1590/ S0100-0683200800060002

Amaral AS, Anghinoni I, Hinrichs R, Bertol I. Movimentação de partículas de calcário no perfil de um Cambissolo em plantio direto. Revisa Brasileira da Ciência do Solo 2004; 28(2): 359-367. 10.1590/ S0100-06832004000200014

Andrade MLF, Boaretto AE. Deficiência nutricional em plantas jovens de aroeira-pimenteira (Schinus terebinthifolius Raddi). Scientia Forestalis 2012; 40(95): 383-392.

Carnevali NHS, Marchetti ME, Vieira MC, Carnevali TO, Ramos DD. Eficiência nutricional de mudas de Stryphnodendron polyphyllum em função de nitrogênio e fósforo. Ciência Florestal 2016; 26(2): 449-461. 10.5902/1980509822746

Cremon C, Rosa EJ Jr, Serafim ME, Ono FB. Análise micromorfométrica de agregados de um Latossolo Vermelho distroférrico em diferentes sistemas de manejo. Acta Scientiarum. Agronomy 2009; 31(1): 139-146. 10.4025/actasciagron.v31i1.6640

Dickson A, Leaf AL, Hosner JF. Quality appraisal of white spruce and white pine seedling stock in nurseries. Forestry Chronicle 1960; 36(1): 10-13.

Dawkins K, Esiobu N. Emerging insights on Brazilian pepper tree (Schinus terebinthifolius) invasion: the potential role of soil microorganisms. Frontiers in Plant Science 2016; 7: 712. 10.3389/ fpls.2016.00712

Donagema GK, Campos DVB, Calderano SB, Teixeira WG, Viana JHM. Manual de métodos de análise de solo. 2nd ed. Rio de Janeiro: Embrapa; 2011.

Eberhardt DN, Vendrame PRS, Becquer T, Guimarães MF. Influência da granulometria e da mineralogia sobre a retenção do fósforo em latossolos sob pastagens no cerrado. Revista Brasileira de Ciência do Solo 2008; 32(3): 1009-1016.

Ernani PR, Bayer C, Almeida JA, Cassol PC. Mobilidade vertical de cátions influenciada pelo método de aplicação de cloreto de potássio em solos com carga variável. Revista Brasileira de Ciência do Solo 2007; 31(2): 393-402. 10.1590/S0100-06832007000200022

Geiger JH, Pratt PD, Wheeler GS, Williams DA. Hybrid vigor for the invasive exotic Brazilian pepper tree (Schinus terebinthifolius Raddi., Anacardiaceae) in Florida. International Journal of Plant Sciences 2011; 172(5): 655-663. 10.1086/659457

Johann S, Cisalpino PS, Watanabe GA, Cota BB, Siqueira EP, Pizzolatti MG et al. Antifungal activity of extracts of some plants used in Brazilian traditional medicine against the pathogenic fungus Paracoccidioides brasiliensis. Pharmaceutical Biology 2010; 48(4): 388-396. 10.3109/13880200903150385

Koester RP, Skoneczka JA, Cary TR, Diers BW, Ainsworth EA. Historical gains in soybean (Glycine max Merr.) seed yield are driven by linear increases in light interception, energy conversion, 
and partitioning efficiencies. Journal of Experimental Botany 2014; 65(12): 3311-3321. 10.1093/jxb/eru187

Lü C, Yan D, He J, Zhou B, Li L, Zheng Q. Environmental geochemistry significance of organic phosphorus: An insight from its adsorption on iron oxides. Applied Geochemistry 2017; 84: 52-60. 10.1016/j.apgeochem.2017.05.026

Malavolta E, Vitti GC, Oliveira SA. Avaliação do estado nutricional das plantas: princípios e aplicações. Piracicaba: Potafos; 1997.

Raij BV. Fertilidade do solo e adubação. Piracicaba: Ceres; 1991.

Ramos BZ, Toledo JPVF, Lima JM, Serafim ME, Bastos ARR, Guimarães PTG et al. Doses de gesso em cafeeiro: influência nos teores de cálcio, magnésio, potássio e $\mathrm{pH}$ na solução de um Latossolo Vermelho distrófico. Revista Brasileira de Ciência do Solo 2013; 37(4): 1018-1026. 10.1590/S0100-06832013000400019

Rampim L, Lana MC, Frandoloso JF, Fontaniva S. Atributos químicos do solo e resposta do trigo e da soja ao gesso em semeadura direta. Revista Brasileira de Ciência do Solo 2011; 35(5): 1687-1698. 10.1590/ S0100-06832011000500023

Santos HG, Jacomine PKT, Anjos LHC, Oliveira VA, Oliveira JB, Coelho MR et al. Sistema brasileiro de classificação de solos. 3rd ed. Brasília: Embrapa; 2013.
Santos JZL, Resende AV, Furtini Neto AE, Corte EF. Crescimento, acúmulo de fósforo e frações fosfatadas em mudas de sete espécies arbóreas nativas. Revista Árvore 2008; 32(5): 799-807. 10.1590/ S0100-67622008000500003

Silva FC, Eira PA, Barreto WO, Pérez DV, Silva CA. Métodos de análises químicas para avaliação da fertilidade do solo. In: Silva FC, editor. Manual de análises químicas de solos, plantas e fertilizantes. 2nd ed. Brasília: Embrapa; 2009. p. 107-184.

Soratto RP, Crusciol CAC. Métodos de determinação de cálcio e magnésio trocáveis e estimativa do calcário residual em um Latossolo submetido à aplicação de calcário e gesso em superfície. Revista Brasileira de Ciência do Solo 2008; 32(2): 663-673. 10.1590/S010006832008000200021

Weraduwage SM, Chen J, Anozie FC, Morales A, Weise SE, Sharkey TD. The relationship between leaf area growth and biomass accumulation in Arabidopsis thaliana. Frontiers in Plant Science 2015; 6: 167. 10.3389/fpls.2015.00167

Werle R, Garcia RA, Rosolem CA. Lixiviação de potássio em função da textura e da disponibilidade do nutriente no solo. Revista Brasileira de Ciência do Solo 2008; 32(6): 2297-2305. 10.1590/ S0100-06832008000600009 